\title{
Mesoscale Physical-Biological-Biogeochemical Linkages in the Open Ocean: An Introduction to the results of the E-Flux and EDDIES Programs
}

\author{
Claudia R. Benitez-Nelson ${ }^{1}$ and Dennis J. McGillicuddy, $\mathrm{Jr}^{2}{ }^{2}$ with contributions from E- \\ Flux and EDDIES collaborators \\ ${ }^{1}$ Department of Geological Sciences, University of South Carolina, Columbia, SC 29208 \\ ${ }^{2}$ Department of Applied Ocean Physics and Engineering, Woods Hole Oceanographic \\ Institution, Woods Hole, MA 02543 \\ * Corresponding Author, Email: cbnelson@geol.sc.edu, Tel: 803-777-0018 \\ Fax: 803-777-6610
}

\section{PREFACE}

Mesoscale currents, fronts, and eddies are ubiquitous and energetic features of ocean circulation. These phenomena, sometimes referred to as the "internal weather of the sea," accommodate a diverse set of physical, chemical, and biological interactions that influence marine biogeochemistry on a wide range of timescales. These biogeochemical processes include the "biological pump", i.e. the transfer or flux of biologically produced organic matter and associated elements from the surface ocean to depth (Ducklow et al., 2001; Volk and Hoffert, 1985). Within $\sim 80 \%$ of the world's oceans, the productivity and species composition of the autotrophic organisms that contribute to the biological pump are typically limited by major nutrients (e.g. nitrogen, phosphorus, and silica), or trace metals (e.g. iron). Primary production in such oligotrophic regions therefore depends mostly on intense recycling of nutrients within the surface sunlit waters, with only a small fraction supported by that entering from the atmosphere, or from the physical transport of nutrients from nutrient-rich deep waters below. Evidence that mesoscale and submesoscale phenomena play a role in the latter process dates back more than two decades (Angel and Fasham, 1983; Franks et al., 1986; Ring Group, 1981; Tranter et al., 1980; Venrick, 1990; Woods, 1988).

In the open ocean there are several common types of eddies. In the northern hemisphere, cyclones tend to create a doming of the seasonal and main pycnoclines, while anticyclones depress both. Mode-water eddies (MWEs) are anticyclonic in rotation; however the seasonal pycnocline domes while the main thermocline is depressed (McGillicuddy et al., 1999). Wind-driven eddies in the lee of Hawaii can be either cyclonic or anticyclonic; cyclonic lee eddies are surface intensified features that dome the seasonal thermocline (Lumpkin, 1998; Patzert, 1969). In the Sargasso Sea, cyclones and MWEs have been hypothesized to reconcile differences between tracer-based estimates of new production and traditional ship-board methods that may miss eddy-induced biological activity (Jenkins, 1988). Estimates of the integrated impact of eddy-driven nutrient fluxes vary considerably, from less than $10 \%$ to more than $50 \%$ of annual new 
production (Falkowski et al., 1991; Martin and Pondaven, 2003; McGillicuddy et al., 2003; Oschlies, 2002; Oschlies and Garcon, 1998; Siegel et al., 1999; Williams and Follows, 2003).

The following compendium of papers focuses on results from interdisciplinary programs carried out in the subtropical North Pacific (E-Flux) and North Atlantic (EDDIES). The structure of this volume reflects the studies' main goals. The first section focuses on characterizing eddy-induced perturbations of the physical and bio-optical environment using tracer release (Ledwell et al., 2008) and a variety of shipboard, drifter, and satellite measurements (Dickey et al., 2008; Greenan, 2008; Kuwahara et al., 2008; Nencioli et al., 2008; Siegel et al., 2008). These studies also include the results of model formulations that confirm the importance of winds and topography on Hawaiian eddy formation and propagation (Calil et al., 2008). The second section delves into the plankton community response, with papers discussing nutrient distributions ( $\mathrm{Li}$ and Hansell, 2008; Rii et al., 2008), plankton community structure (Bibby et al., 2008; Brown et al., 2008; Ewart et al., 2008; Rii et al., 2008), growth, grazing, and metabolic balance, (Bibby et al., 2008; Landry et al., 2008a; McAndrew et al., 2008) and the influence of eddies on higher trophic levels (Goldthwait and Steinberg, 2008; Landry et al., 2008b). The third section concentrates on the resulting impacts on biogeochemical cycling and export. It includes discussions of nutrient fluxes (Jenkins et al., 2008), inorganic carbon and nutrient mass balance (Chen et al., 2008; Mahaffey et al., 2008) as well as sinking particle fluxes derived using radionuclide disequilibria (Buesseler et al., 2008; Maiti et al., 2008; Verdeny et al., 2008). Last is a section that examines the impact of eddies on trace elements and gases, including hybrid-type metals in the Pacific (Noble et al., 2008) and dimethylsulfide production and distributions in the Atlantic (Bailey et al., 2008; Gabric et al., 2008).

The E-Flux program was comprised of three cruises in the lee of the Hawaiian Islands that sampled two cold-core cyclonic eddies of different ages (Benitez-Nelson et al., 2007; Dickey et al., 2008). Cyclone Noah, a 2.5-month-old mature feature when sampled, was characterized by relatively modest perturbations in chlorophyll and phytoplankton composition with respect to ambient conditions (Kuwahara et al., 2008; Rii et al., 2008). In contrast, younger and stronger Cyclone Opal contained a substantial diatom bloom that decayed during the nine days over which it was sampled (Brown et al., 2008; Landry et al., 2008b; Nencioli et al., 2008; Rii et al., 2008). Within the deep chlorophyll maximum (DCM) at Opal's center, photosynthetically active (high $\left.\mathrm{F}_{\mathrm{v}} / \mathrm{F}_{\mathrm{m}}\right)$ diatoms, such as the chain-forming Chaetoceros spp. were $\sim 100$ times higher in biomass (Bibby et al., 2008; Brown et al., 2008) and 60 times higher in diatom pigment concentrations (Rii et al., 2008) than that observed in ambient waters. Enhanced phytoplankton growth rates induced a shift from net heterotrophy to net autotrophy (McAndrew et al., 2008) and were accompanied by an increase in microzooplankton grazing (Landry et al., 2008a). Noble et al. (2008) describe mesoscale variations in the distribution of cobalt, manganese, and iron, and suggest an eddy-driven concentrating mechanism to explain their Cyclone Opal observations. 
EDDIES (EDdy Dynamics, mixing, Export, and Species composition) sampled ten different eddies in varying degrees of detail in the Sargasso Sea off Bermuda (McGillicuddy et al., 2007). The results presented herein mainly focus on repeat occupations of two target eddy features, cyclone $\mathrm{C} 1$ and mode-water eddy A4. Cyclone C1 was several months old when it was first sampled. Although nutrients and chlorophyll were enhanced at the center of C1 (Li and Hansell, 2008), the cyclone was populated with a nano- to pico-phytoplankton community typical of the region (Bibby et al., 2008; Ewart et al., 2008). Unlike Cyclone Opal, net community production experiments suggested a transition from net autotrophy to net heterotrophy during the course of the observations made in C1 (Mourino-Carballido and McGillicuddy, 2006). MWE A4 was also several months old at the time of first sampling, but it contained extraordinary diatom biomass (Bibby et al., 2008; Ewart et al., 2008; McGillicuddy et al., 2007) that persisted throughout six occupations during the ten weeks of observations. The peak chlorophyll concentration measured at eddy center exceeded all prior observations at the nearby Bermuda Atlantic Time-series Study (BATS) site, 8 standard deviations higher than the mean DCM measured at BATS (McGillicuddy et al., 2007). Microscope counts from a sample in the high-chlorophyll region revealed the diatom assemblage within MWE A4 was dominated by colonies of Chaetoceros spp., present in concentrations of ca. 8000 colonies $1^{-1}$, with each colony containing ca. 15 cells. Given background diatom cell concentrations of 1 to 50 cells $1^{-1}$ (Goldman and McGillicuddy, 2003; Guillard and Kilham, 1977; Hulburt, 1990), diatom concentrations were 2400 to 100,000 times higher than ambient waters. Diatom pigment biomass was 5-8 standard deviations above the BATS long-term average (Ewart et al., 2008; McGillicuddy et al., 2007). Both $\mathrm{C} 1$ and $\mathrm{A} 4$ contained elevated zooplankton biomass, suggesting eddy-driven impacts on higher trophic levels as well (Goldthwait and Steinberg, 2008). Sargasso Sea eddies were also used as natural laboratories for studies of dimethylsulfide (DMS) cycling in an effort to help explain the so-called "DMS summer paradox" characterized by peak DMS concentrations during periods when biomass and productivity are at their seasonal minima. Bailey et al. (2008) and Gabric et al. (2008) incorporate lagrangianbased observations from two eddies into one-dimensional numerical models, exploiting the physical and biological differences in two features to expose the mechanisms responsible for structuring the mean DMS profile.

Why are the biological and biogeochemical responses within the sampled eddies so different and complex? It is likely due to a combination of variations in the magnitude, timing, and duration of nutrient input caused by differences in eddy formation, intensity, age, and movement as shown in this volume and previously (Bibby et al., 2008; Brown et al., 2008; McGillicuddy et al., 1999; Nencioli et al., 2008; Olaizola et al., 1993; Rii et al., 2008; Sweeney et al., 2003). For example, Hawaiian lee cyclones (and anticyclones) appear to be wind-driven, formed by a combination of strong northeasterly winds and island topography (Chavanne et al., 2002; Lumpkin, 1998; Patzert, 1969), whereas midocean eddies in the Sargasso Sea are formed by instability processes that feed on the larger scale flow (Robinson, 1983). Once formed, cyclones and MWEs may also respond differently to eddy-wind interactions. A spatially uniform wind forcing over an eddy gives rise to mesoscale variations in surface stress because the wind blows in the same direction on one flank of the eddy and opposes it on the other. This effect causes 
upwelling in the interiors of anticyclones (Dewar and Flierl, 1987; Martin and Richards, 2001), which reinforces eddy-induced upwelling in MWEs (Ledwell et al., 2008;

McGillicuddy et al., 2007). In contrast, this same type of eddy-wind interaction tends to depress the isopycnal uplift associated with cyclones (McGillicuddy et al., 2007).

Despite the many differences among the eddies sampled by the two programs, it is clear that cyclones in both the Atlantic and Pacific can result in substantial nutrient injection. Cyclones Opal and $\mathrm{C} 1$ were both relatively strong features, with eddy-induced nitrate injections estimated to be $0.2 \mathrm{~mol} \mathrm{~m}^{-2}$ (Mahaffey et al., 2008) and $1.4 \mathrm{~mol} \mathrm{~m}^{-2}$ (Jenkins et al., 2008), respectively. Interestingly, of all the cyclones that have been sampled intensively in the lee of Hawaii (Table 1) and in the Sargasso Sea (Table S1, (McGillicuddy et al., 2007), only Cyclone Opal contained an extraordinary diatom bloom. Others contained more modest enhancements of diatoms (a factor of two or less), whereas some did not appear to perturb phytoplankton community structure at all (Table 1).

Why was Cyclone Opal unique in this regard? Cyclone Opal was characterized by very large isopycnal displacements of over $100 \mathrm{~m}$ at the eddy core relative to surrounding waters (Table 1) and was less than 6 weeks in age (Dickey et al., 2008; Nencioli et al., 2008). The only other Hawaiian cyclone studied to date to have similarly large displacements in isopycnal surfaces was Cyclone Haulani, a month older (Table 1, and see Figure 2, Vaillancourt et al., 2003), yet no increase in diatom biomass was observed. However, Vaillancourt et al. (2003) report a relative minimum in Si:N within Haulani's core, consistent with a prior diatom bloom. Thus, older Cyclone Haulani may have already peaked in diatom biomass prior to sampling. That being said, eddy age may not be the only issue. As Rii et al.(2008) and Brown et al. (2008) point out, the absolute magnitude and rate of nutrient injection, e.g. due to wind intensity and/or eddy movement (Nencioli et al., 2008), at any point within an eddy's life cycle may influence the composition of the biological community. For example, Cyclone Noah, at 2.5 months of age, was relatively weak and provided no evidence that a substantial diatom bloom had ever occurred. The same is true for young (1 month) and weak Cyclone Mikalele, whereas Cyclone Loretta was older (6 months) yet still strong enough that it accommodated a two-fold enhancement in diatoms (Seki et al., 2001; Table 1).

Why hasn't a diatom bloom similar to that found in Opal ever been observed in a Sargasso Sea cyclone? The answer may in part be due to sampling. The E-Flux experimental design took advantage of predictability in the formation region for winddriven cyclones, and sampling of a young and strong cyclone revealed the presence of diatoms in large numbers. However, that response was ephemeral, as diatom abundance decreased by 50\% during the 9 days the E-Flux team was on site (Brown et al., 2008; Rii et al., 2008). In contrast, formation of cyclones in the Sargasso Sea is unpredictable by virtue of the geophysical turbulence processes that create them. These features are detectable by satellite altimetry (and more weakly in ocean color; Siegel et al., 2008), but sampling thus far may have been biased toward mature cyclones with stronger expressions in satellite observations. As a result, if diatom blooms have occurred in the 
initial formation and intensification phases of Sargasso Sea cyclones, they could have been missed (McGillicuddy et al., 2007; Bibby et al., 2008).

In contrast to cyclones in the Sargasso Sea and in the lee of Hawaii, Sargasso Sea MWEs have a tendency to contain significant numbers of diatoms, regardless of eddy age (McGillicuddy et al., 2007; McNeil et al., 1999; Sweeney et al., 2003). Sustenance of longer-lasting diatom blooms inside MWEs may be due to upwelling driven by eddywind interactions described above as well as enhanced mixing caused by trapping of near-inertial motions (Kunze, 1985). Evidence of both mechanisms was revealed in the tracer release experiment in MWE A4 (Ledwell et al., 2008), and fine-structure measurements in the core of that feature are consistent with enhanced mixing (Greenan, 2008). Although the nutrient flux of $0.6 \mathrm{mmol} \mathrm{N} \mathrm{m}^{-2} \mathrm{~d}^{-1}$ inferred from the tracer release experiment in MWE A4 is not particularly large (Ledwell et al., 2008), the character of the ${ }^{3} \mathrm{He}-\mathrm{NO}_{3}$ relationship suggests steady upwelling (Jenkins et al., 2008). Thus, we hypothesize that it is the persistence of the nutrient flux that leads to the extraordinary biological response in MWE A4.

Given the strong biological responses of large phytoplankton in Cyclone Opal and MWE A4 it is surprising that neither feature showed any direct evidence of enhanced overall particulate carbon export either by sediment traps or by ${ }^{234} \mathrm{Th}:{ }^{238} \mathrm{U}$ and ${ }^{210} \mathrm{~Pb}:{ }^{210} \mathrm{Po}$ disequilibria during the field campaigns (Buesseler et al., 2008; Maiti et al., 2008; Rii et al., 2008; Verdeny et al., 2008). Rather, enhanced export was only observed in particulate silica, with a small increase in zooplankton fecal pellet production. Silica export was three to four times higher than ambient waters in both Cyclone Opal (Maiti et al., 2008; Rii et al. 2008; Verdeny et al., 2008) and MWE A4 (Buesseler et al., 2008), suggesting that eddies may play a role in the removal of silicate from surface waters. Enhanced silicate removal would thus drive these already oligotrophic systems towards silica stress and minimize the potential for diatom growth in future upwelling events (Benitez-Nelson et al., 2007; Rii et al., 2008). Additionally, enhanced zooplankton fecal pellet flux was observed in Cyclone $\mathrm{C} 1$ and MWE A4. Although increased fecal pellet POC flux did not enhance overall particulate $\mathrm{C}$ flux, eddies appear to affect higher trophic level community structure which in turn influences the composition and quantity of sinking particles (Goldthwait and Steinberg, 2008).

Although significant enhancement of particulate carbon flux was not observed in either E-Flux or EDDIES field programs, it is possible that the export events were somehow missed. Both $\mathrm{C} 1$ and $\mathrm{A} 4$ contained mesopelagic oxygen anomalies that, if interpreted as the geochemical signature of prior export events, amount to 1-3 times annual new production for the region (McGillicuddy et al., 2007), even after accounting for cyclone C1's potential distant water origin (Li et al., Submitted). Why no similar evidence of a large export event has been observed in any of the Hawaiian lee eddies is unknown. According to the "leaky bottom" model proposed by Nencioli et al. (2008), Cyclone Opal may have left a trail of its biological and biogeochemical signature in its wake as it translated, similar to the conceptual model introduced by (Olaizola et al., 1993). This is consistent with the generally shallow penetration of Hawaiian lee eddies and would not allow for a coherent oxygen deficit to form at depth. The same might be true for Cyclone 
Noah, although this eddy remained spatially stable and there is no evidence to suggest that the wake hypothesized in the leaky bottom model occurred (Kuwahara et al., 2008).

The biomass produced by eddy-induced blooms may also have fates other than particle export. Observations within Cyclone Opal indicate that rapid microzooplankton grazing by large $(>50 \mu \mathrm{m})$ ciliates and dinoflagellates released suspended and dissolved organic matter (Landry et al., 2008b) rather than producing fecal pellets. This finding is consistent with mass balance estimates of nutrients and inorganic and organic carbon, which suggests that most of the new production within Cyclone Opal accumulated as dissolved organic matter (Chen et al., 2008). In contrast, Li et al. (submitted) found no evidence of dissolved organic matter accumulation within the euphotic zone in cyclone C1.

It is important to note here that zooplankton may play a role in organic matter transport beyond fecal pellet production. Both Goldthwait and Steinberg (2008) and Landry et al. (2008b) found an increase in mesozooplankton biomass and grazing within MWE A4 and Cyclone Opal, respectively, which resulted in migrant mediated active export fluxes that were 43 and $50 \%$ of that measured within corresponding sediment trap deployments. Within Cyclone Opal, active transport may reconcile ${ }^{15} \mathrm{~N}$ based nitrogen mass balance estimates (Landry et al., 2008b). However, active transport is still not sufficient to explain the magnitude of the oxygen deficits observed at depth in cyclone $\mathrm{C} 1$ or MWE A4 (Goldthwait and Steinberg, 2008).

The mechanisms that control export of material out of the euphotic zone thus remain enigmatic. In neither the Pacific nor the Atlantic are the observed particle fluxes sufficient to balance geochemical estimates of new production (e.g. Jenkins, 1982; Schulenberger and Reid, 1981). One hypothesis underlying both the E-Flux and EDDIES programs was that episodic pulses of organic matter might be undersampled in existing databases, perhaps explaining the imbalances in mass budgets computed from time-series observations (e.g. Michaels et al., 1994). Although the deep oxygen anomalies present in $\mathrm{C} 1$ and $\mathrm{A} 4$ are suggestive of significant export events, the fact remains that neither EFlux nor EDDIES were able to directly measure substantially enhanced particulate carbon fluxes associated with mesoscale eddies. While sampling may still be an issue, it is clear that the rarer such export events are, the more extraordinary the particle fluxes will have to be in order to dominate the mean flux.

Acknowledgements. We are grateful for the hard work and dedication by all investigators involved in the E-Flux and EDDIES projects. E-Flux and EDDIES were supported by the National Science Foundation Chemical, Biological, and Physical Oceanography Programs. Additional support for the EDDIES project was provided by NASA.

\section{References}

Allen, C.B., Kanda, J. and Laws, E.A., 1996. New production and photosynthetic rates within and outside a cyclonic mesoscale eddy in the North Pacific subtropical gyre. Deep-Sea Research Part I-Oceanographic Research Papers, 43(6): 917-936. 
Angel, M.V. and Fasham, M.J.R., 1983. Eddies and Biological Processes. In: A.R. Robinson (Editor), Eddies in Marine Science. Springer-Verlag.

Bailey, K.E. et al., 2008. Dimethylsulfide production in Sargasso Sea eddies. Deep Sea Research II.

Benitez-Nelson, C.R. et al., 2007. Mesoscale eddies drive increased silica export in the subtropical Pacific Ocean. Science, 316(5827): 1017-1021.

Bibby, T.S., Gorbunov, M.Y., Wyman, K.W. and Falkowski, P.G., 2008. Photosynthetic community responses to upwelling mesoscale eddies in the subtropical north Atlantic and Pacific Oceans. Deep Sea Research II.

Bidigare, R.R. et al., 2003. Influence of a cyclonic eddy on microheterotroph biomass and carbon export in the lee of Hawaii. Geophysical Research Letters, 30(6): 1318.

Brown, S.L. et al., 2008. Diatoms in the Desert. Deep Sea Research II.

Buesseler, K.O. et al., 2008. Particle fluxes associated with mesoscale eddies in the Sargasso Sea. Deep Sea Research II.

Calil, P.H.R., Richards, K., Jia, Y. and Bidigare, R.R., 2008. Eddy Activity in the Lee of the Hawaiian Islands. Deep Sea Research II.

Chavanne, C., Flament, P., Lumpkin, R., Dousset, B. and Bentamy, A., 2002. Scatterometer observations of wind variations by oceanic islands: Implications for wind driven ocean circulation. Canadian Journal of Remote Sensing, 28: 466-474.

Chen, F. et al., 2008. The carbon dioxide system and net community production within a cyclonic eddy in the lee of Hawaii. Deep Sea Research II.

Dewar, W.K. and Flierl, G.R., 1987. Some Effects of the Wind on Rings. Journal of Physical Oceanography, 17(10): 1653-1667.

Dickey, T. et al., 2008. Physical and Bio-optical Observations of Oceanic Cyclones West of the Island of Hawaii. Deep Sea Research II.

Ducklow, H., Steinberg, D.K. and Buesseler, K.O., 2001. Upper ocean carbon export and thebiological pump. Oceanography, 14: 50-58.

Ewart, C.S., Meyers, M.K., Wallner, E., McGillicuddy, D.J. and Carlson, C.A., 2008. Bacterioplankton Dynamics in Cyclonic and Anticyclonic Mode-Water Eddies in the Northwestern Sargasso Sea. Deep Sea Research II.

Falkowski, P., Zieman, D., Kolber, Z. and Bienfang, P., 1991. Role of eddy pumping in enhancing primary production in the ocean. Nature, 353: 55-58.

Franks, P.J.S., Wroblewski, J.S. and Flierl, G.R., 1986. Prediction of phytoplankton growth in response to the frictional decay of a warm-core ring. Journal of Geophysical Reseach, 91: 7603-7610.

Gabric, A.J. et al., 2008. Factors determining the vertical profile of dimethylsulfide in the Sargasso Sea during summer. Deep Sea Research II.

Goldman, J.C. and McGillicuddy, D.J., 2003. Effect of large marine diatoms growing at low light on episodic new production. Limnology and Oceanography, 48(3): 1176-1182.

Goldthwait, S.A. and Steinberg, D.K., 2008. Elevated Biomass of Mesozooplankton and Enhanced Fecal Pellet Flux in Cyclonic and Mode-Water Eddies in the Sargasso Sea. Deep Sea Research II.

Greenan, B.J.W., 2008. Shear and Richardson number in a mode-water eddy. Deep Sea Research II. 
Guillard, R.R.L. and Kilham, P., 1977. The ecology of marine panktonic diatoms. In: D. Werner (Editor), The Biology of Diatoms. University of California Press, pp. 372459.

Hulburt, E.M., 1990. Description of Phytoplankton and Nutrient in Spring in the Western North-Atlantic Ocean. Journal of Plankton Research, 12(1): 1-28.

Jenkins, W.J., 1988. The use of anthropogenic tritium and helium-3 to study subtropical gyre ventilation and circulation. Philos. Trans. R. Soc. London Ser. A., 325: 4361.

Jenkins, W.J., McGillicuddy, D.J. and Lott, D.E., 2008. The distributions of, and relationship between, $3 \mathrm{He}$ and nitrate in eddies. Deep Sea Research II.

Kunze, E., 1985. Near-Inertial Wave-Propagation in Geostrophic Shear. Journal of Physical Oceanography, 15(5): 544-565.

Kuwahara, V.S., Nencioli, F., Dickey, T.D., Rii, Y.M. and Bidigare, R.R., 2008. Physical Dynamics and Biological Implications of Cyclone Noah in the Lee of Hawai'i during E-Flux I. Deep-Sea Research II.

Landry, M.R. et al., 2008a. Depth-stratified phytoplankton dynamics in Cyclone Opal, a subtropical mesoscale eddy. Deep Sea Research II.

Landry, M.R., Decima, M., Simmons, M.P., Hannides, C.C.S. and Daniels, E., 2008 b. Mesozooplankton biomass and grazing responses to Cyclone Opal, a subtropical mesoscale eddy.

Ledwell, J.R., McGillicuddy, D.J. and Anderson, L.A., 2008. Nutrient flux into an intense deep chlorophyll layer in a mode-water eddy. Deep Sea Research II.

Li, Q.P. and Hansell, D.A., 2008. Nutrient distributions in baroclinic eddies of the oligotrophic North Atlantic and inferred impacts on biology. Deep-Sea Research II.

Li, Q.P., Hansell, D.A., McGillicuddy, D.J., Bates, N.R. and Johnson, R.J., Submitted. Biogeochemical impacts of a cyclonic eddy in the Sargasso Sea. Deep Sea Research I.

Lumpkin, C.F., 1998. Eddies and currents in the Hawaii islands, University of Hawaii, Honolulu.

Mahaffey, C., Benitez-Nelson, C.R., Bidigare, R.R., Rii, Y. and Karl, D.M., 2008. Nitrogen dynamics within a wind-driven eddy. Deep Sea Research II.

Maiti, K., Benitez-Nelson, C.R., Rii, Y. and Bidigare, R.R., 2008. The influence of a mature cyclonic eddy on particle export in the lee of Hawaii. Deep Sea Research II.

Martin, A.P. and Pondaven, P., 2003. On estimates for the vertical nitrate flux due to eddy-pumping. Journal of Geophysical Research, 108(C11): 3359, doi: 10.1029/2003JC001841.

Martin, A.P. and Richards, K.J., 2001. Mechanisms for vertical nutrient transport within a North Atlantic mesoscale eddy. Deep-Sea Research Part Ii-Topical Studies in Oceanography, 48(4-5): 757-773.

McAndrew, P.M., Bidigare, R.R. and Karl, D.M., 2008. Primary production and implications for metabolic balance in Hawaiian lee eddies. Deep Sea Research II.

McGillicuddy, D. et al., 1999. Mesoscale variations of biogeochemical properties in the Sargasso Sea. Jounral of Geophysical Reseach-Oceans, 104(C6): 13,381-13,394. 
McGillicuddy, D.J. et al., 2007. Eddy/wind interactions stimulate extraordinary midocean plankton blooms. Science, 316(5827): 1021-1026.

McGillicuddy, D.J., Anderson, L.A., Doney, S.C. and Maltrud, M.E., 2003. Eddy-driven sources and sinks of nutrients in the upper ocean: Results from a $0.1^{\circ}$ resolution model of the North Atlantic. Global Biogeochemical Cycles, 17(2): 1035 doi:1010.1029/2002GB001987.

McNeil, J.D. et al., 1999. New chemical, bio-optical and physical observations of upper ocean response to the passage of a mesoscale eddy off Bermuda. Journal of Geophysical Research-Oceans, 104(C7): 15537-15548.

Michaels, A.F., Bates, N.R., Buesseler, K.O., Carlson, C.A. and Knap, A.H., 1994. Carbon-Cycle Imbalances in the Sargasso Sea. Nature, 372(6506): 537-540.

Mourino-Carballido, B. and McGillicuddy, D.J., 2006. Mesoscale variability in the metabolic balance of the Sargasso Sea. Limnology and Oceanography, 51(6): 2675-2689.

Nencioli, F., Kuwahara, V.S., Dickey, T.D., Rii, Y.M. and Bidigare, R.R., 2008. Physical dynamics and biological implications of a mesoscale eddy in the lee of Hawai'i: Cyclone Opal observations during E-Flux III. Deep Sea Research II.

Noble, A.E., Saito, M.A., Maiti, K. and Benitez-Nelson, C.R., 2008. Cobalt, manganese, and iron near the Hawaiian Islands: A potential concentrating mechanism for cobalt within a cyclonic eddy and implications for the hybrid-type trace metals. Deep Sea Research II.

Olaizola, M., Ziemann, D.A., Bienfang, P.K., Walsh, W.A. and Conquest, L.D., 1993. Eddy-Induced Oscillations of the Pycnocline Affect the Floristic Composition and Depth Distribution of Phytoplankton in the Subtropical Pacific. Marine Biology, 116(4): 533-542.

Oschlies, A., 2002. Can eddies make ocean deserts bloom? Global Biogeochemical Cycles, 16: 1106, doi:10.1029/2001GB001830.

Oschlies, A. and Garcon, V., 1998. Eddy-induced enhancement of primary production in a model of the north Atlantic Ocean. Nature, 394(6690): 266-269.

Patzert, W., 1969. Eddies in Hawaiian Islands Report No. HIG-69-8, University of Hawaii, Hawaii Institute of Geophysics.

Rii, Y.M. et al., 2008. The transient oasis: Nutrient-phytoplankton dynamics and particle export in Hawaiian lee cyclones. Deep Sea Research II.

Ring Group, 1981. Gulf-Stream Cold-Core Rings - Their Physics, Chemistry, and Biology. Science, 212(4499): 1091-1100.

Robinson, A.R., 1983. Eddies in Marine Science. Springer Verlag, NewYork.

Seki, M.P. et al., 2001. Biological enhancement at cyclonic eddies tracked with GOES thermal imagery in Hawaiian waters. Geophysical Research Letters, 28(8): 15831586.

Siegel, D.A. et al., 2008. Satellite and in situ observations of the bio-optical signatures of two mesoscale eddies in the Sargasso Sea. Deep Sea Research II.

Siegel, D.A., McGillicuddy, D.J. and Fields, E.A., 1999. Mesoscale eddies, satellite altimetry, and new production in the Sargasso Sea. Journal of Geophysical Research-Oceans, 104(C6): 13359-13379.

Sweeney, E.N., McGillicuddy, D.J. and Buesseler, K.O., 2003. Biogeochemical impacts due to mesoscale eddy activity in the Sargasso Sea as measured at the Bermuda 
Atlantic Time-series Study (BATS). Deep Sea Research Part II: Topical Studies in Oceanography

The US JGOFS Synthesis and Modeling Project: Phase II, 50(22-26): 3017-3039.

Tranter, D.J., Parker, R.R. and Cresswell, G.R., 1980. Are Warm-Core Eddies Unproductive. Nature, 284(5756): 540-542.

Vaillancourt, R., Marra, J., Seki, M., Parsons, M. and Bidigare, R., 2003. Impact of a cyclonic eddy on phytoplankton community structure and photosynthetic competency in the subtropical North Pacific Ocean. Deep Sea Research I, 50: 829-847.

Venrick, E.L., 1990. Mesoscale Patterns of Chlorophyll-a in the Central North Pacific. Deep-Sea Research Part a-Oceanographic Research Papers, 37(6): 1017-1031.

Verdeny, E. et al., 2008. Particle Export within cyclonic Hawaiian lee eddies derived from 210Pb-210Po disequilibria. Deep Sea Research II.

Volk, T. and Hoffert, M.I., 1985. Ocean carbon pumps: Analysis of relative strengths and efficiencies in ocean-driven atmospheric $\mathrm{CO} 2$ changes. Geophysical Monographs, 32: 99-110.

Williams, R.G. and Follows, M.J., 2003. Physical transport of nutrients and the maintenance of biological production. In: M.J.R. Fasham (Editor), Ocean Biogeochemistry: The role of the ocean carbon cycle in global change. Springer, pp. 19-51.

Woods, J.D., 1988. Mesoscale upwelling and primary production. In: B.J. Rothschild (Editor), Toward a Theory on Biological-Physical Interactions in the World Ocean. D. Reidel, Dordrecht. 
Table 1. Summary of biological/biogeochemical sampling of Hawaiian Lee eddies. The magnitude of the isopycnal or isothermal displacement is used here as a proxy for eddy strength at the time of sampling. Because of seasonal and interannual variations in mean stratification, a single isopycnal or isotherm cannot be used for diagnostic purposes. Instead, an isopycnal/isotherm residing just below the euphotic zone in ambient waters is used.

\begin{tabular}{|c|c|c|c|c|}
\hline Eddy & Reference & $\begin{array}{l}\text { Isopycnal or } \\
\text { isotherm } \\
\text { displacement }\end{array}$ & $\begin{array}{l}\text { Approximate Age } \\
\text { during sampling } \\
\text { (months) }\end{array}$ & Remarks \\
\hline Opal & E-Flux (This Volume) & $\begin{array}{l}\sigma_{\mathrm{t}}=24.2 \\
140-20 \mathrm{~m}\end{array}$ & 1 & $\begin{array}{l}5 \times \text { TChl } a \text { of ambient waters; } \\
\text { diatom biomass } 100 \times \text { ambient } \\
\text { waters }\end{array}$ \\
\hline Noah & E-Flux (This Volume) & $\begin{array}{l}\sigma_{\mathrm{t}}=24.0 \\
140-90 \mathrm{~m}\end{array}$ & 2.5 & $\begin{array}{l}1.1 \times \text { TChl } a \text { of ambient waters; } \\
\text { Prochl. spp., prymn., \& pelago }\end{array}$ \\
\hline Sept. 1989 & $\begin{array}{l}\text { (Allen et al., 1996; } \\
\text { Falkowski et al., 1991; } \\
\text { Olaizola et al., 1993) }\end{array}$ & $\begin{array}{l}\text { Temp }=23^{\circ} \mathrm{C} \\
130-100 \mathrm{~m}\end{array}$ & unknown & $\begin{array}{l}1.3 \text { to } 2.2 \times \text { TChl } a ; \\
\text { prochloro, chloro, } \& \text { chryso }\end{array}$ \\
\hline Mikalele & (Seki et al., 2001) & $\begin{array}{l}\text { Temp }=21^{\circ} \mathrm{C} \\
140-90 \mathrm{~m}\end{array}$ & 1 & $\begin{array}{l}\text { Background TChl } a \text {, } \\
\text { pelago. \& prasin. }\end{array}$ \\
\hline Loretta & (Seki et al., 2001) & $\begin{array}{l}\text { Temp }=23^{\circ} \mathrm{C} \\
140-50 \mathrm{~m}\end{array}$ & 6 & $\begin{array}{l}1.5 \times \mathrm{TChl} a \mathrm{I} \\
\text { diatoms, dinos, \& haptos }\end{array}$ \\
\hline Haulani & $\begin{array}{l}\text { (Bidigare et al., 2003; } \\
\text { Vaillancourt et al., 2003) }\end{array}$ & $\begin{array}{l}\sigma_{t}=23.5 \\
140-0 \mathrm{~m}\end{array}$ & 2 & $\begin{array}{l}1.5 \text { x TChl } a \text {; } \\
\text { Prochl. spp., prymn., diatoms, }\end{array}$ \\
\hline
\end{tabular}


\& dino.

${ }^{\dagger}$ Based on Satellite observations 